\title{
INFLUENCIA DE ORGANIZACIONES EN EL DESARROLLO RURAL: CASO DE SALINAS, SAN LUIS POTOSÍ*
}

\author{
INFLUENCE OF ORGANIZATIONS FOR THE RURAL DEVELOPMENT: \\ THE CASE OF SALINAS, SAN LUIS POTOSÍ
}

\begin{abstract}
Luz María Pérez-Hernández ${ }^{1 \S}$, Benjamín Figueroa-Sandoval², José María Díaz-Puente ${ }^{1}$ y Silvia Xochilt Almeraya-Quintero ${ }^{1}$
'Planificación y Gestión de Proyectos de Desarrollo Rural Sostenible. Universidad Politécnica de Madrid. Ramiro de Maeztu 7. Madrid, España.C.P.28040.(xalmeraya@ colpos.mx), (jm.diazpuente@upm.es). ${ }^{2}$ Campus San Luis Potosí. Colegio de Postgraduados. Agustín de Iturbide 73. Salinas de Hidalgo, San Luis Potosí, México. C. P. 78622. (figueroa@colpos.mx).^Autora para correspondencia: luzma.ph@colpos.mx.
\end{abstract}

\section{RESUMEN}

La organización es considerada como elemento estratégico en el desarrollo de una localidad rural, ya que a través de ésta se obtienen mayores beneficios, permite a las personas desarrollar sus capacidades y son impulsoras de proyectos dentro de las comunidades. Sin embargo, es común que los territorios rurales cuenten con un tejido asociativo desarticulado que limita esas posibilidades. Por lo anterior se planteo conocer las causas de la escasa participación de la sociedad en grupos organizados y la problemática que enfrentan las organizaciones asentadas en un territorio, a través de un estudio de caso en el municipio de Salinas, San Luis Potosí, México, en 2009. El objetivo de este trabajo es identificar las causas que están originando que la organización no tenga impacto en el municipio, lo que permitirá formular una estrategia para lograr que ésta sea un motor de desarrollo en el territorio. Los resultados indican que la mayoría de las personas no participan en ningún tipo de organización aún cuando les gusta trabajar en grupo. En general, las organizaciones se enfrentan a dificultades para tomar acuerdos y cumplir los compromisos adquiridos. Las organizaciones formales en el municipio incluyen organizaciones económicas y de representación. Ambas presentan problemas internos relacionados con la falta de recursos económicos, la escasa capacitación y la falta de

\section{ABSTRACT}

The organization is considered as a strategic element in the development of a rural locality, because through it higher benefits are obtained, it allows people to develop their skills and promotes projects within the communities. However, it is common that rural areas have a dismantled association network that limits those possibilities. For that reason, the causes of low society's participation in organized groups and the problems faced by organizations were tried to know; based in a case study in the municipality of Salinas, San Luis Potosí, Mexico, in 2009. The aim of this paper is to identify the reasons why an organization does not have an impact on the municipality, allowing the formulation of a strategy and make it be an engine of development in the territory. The results indicate that most people do not participate in any organization even when they like working in groups. In general, organizations are finding it difficult to make arrangements and meet commitments. Formal organizations in the municipality include economic and representative organizations. Both have internal problems related to lack of funding, poor training and lack of commitment of the group; these elements have not allowed their consolidation and their participation in municipality's development.

\footnotetext{
* Recibido: septiembre de 2010

Aceptado: julio de 2011
} 
compromiso del grupo; elementos que no han permitido su consolidación y su participación en el desarrollo del territorio.

Palabras clave: objetivos, participación, territorio.

\section{INTRODUCCIÓN}

Las condiciones de pobreza en que se encuentra la población rural hace necesaria la búsqueda de alternativas de desarrollo que permitan mejorar sus condiciones de vida. Araujo (1982) señala que los contenidos esenciales de las transformaciones que implican un proceso de desarrollo, se vinculan con la búsqueda de niveles crecientes en los ingresos y su distribución igualitaria por habitante y en la participación de todos los grupos sociales en las decisiones que los afectan. En este sentido, el desarrollo local implica utilizar estrategias, donde se utilicen las dinámicas de organización social, articulando y coordinando los esfuerzos aislados de organizaciones y actores sociales para integrarlos en proyectos participativos con estructuras flexibles, pero en un mismo espacio local, integrando a la sociedad (Contreras, 2000); lo que trae como consecuencia procesos efectivos de comunicación entre los actores de una región(Cebrián, 2003).

Desde esta perspectiva cobra importancia la participación, convirtiéndose en el instrumento clave para el desarrollo económico y social (Nogueira, 1996). Carpio (2001) señala que las iniciativas de desarrollo solo pueden abordar estrategias sostenibles, si consideran que los colectivos sociales actúan inteligentemente y tienen capacidad para analizar la realidad y responder a los problemas.

Una expresión de la participación que ha adquirido una creciente importancia en las sociedades contemporáneas es la formación de organizaciones, entendidas como agrupamientos voluntarios de personas unidas por metas comunes, reglas de funcionamiento y elementos simbólicos que dan identidad (Calvillo y Fabela, 2004).

La FAO (1994) menciona que las organizaciones rurales son agrupaciones de base, formales o informales, voluntarias, democráticas, cuyo fin primario es promover los objetivos económicos o sociales de sus miembros. Independientemente de su situación jurídica o grado de formalización, se caracterizan por ser grupos de personas que tienen por lo menos un objetivo común.
Key words: objectives, participation, territory.

\section{INTRODUCTION}

The poverty of rural population makes it necessary to search for development alternatives in order to improve their living conditions. Araujo (1982), points out that essential contents of transformations that involve a development process, are linked to the search for increasing levels of income and equal distribution per capita and the participation of all social groups in decisions that affect them. In this regard, local development involves using strategies with dynamics of social organization, linking and coordinating the individual efforts of organizations and social actors, to integrate them in participatory projects with flexible structures in the same local space, integrating the society (Contreras, 2000); which results in effective communication processes between actors in a region (Cebrián, 2003).

From this perspective, participation becomes important because is the key instrument for economic and social development (Nogueira, 1996). Carpio (2001), notes that development initiatives can only approach sustainable strategies, if they consider that social groups act intelligently and have the capacity to analyze reality and respond to problems.

An expression of participation that has become increasingly important in contemporary societies is the formation of organizations, defined as voluntary grouping of people united by common goals, operating rules and symbolic elements that give them identity (Calvillo and Fabela, 2004).

FAO (1994), mentions that rural organizations are grassroots groups, formal or informal, voluntary, democratic; whose primary purpose is to promote economic or social objectives of its members. Regardless of their legal status or formality degree, they are characterized by being groups of people who have at least one common goal.

Several authors agree that small farmers, rural workers, landless peasants and other disadvantaged groups of rural population, do not have sufficient bargaining power to ensure that their requests are met. Hence the importance of 
Varios autores coinciden en que los pequeños agricultores, trabajadores rurales, campesinos sin tierra, y otros grupos desaventajados de la población rural no tienen poder de negociación suficiente para lograr que sus peticiones sean atendidas. De ahí la importancia de agruparse y unir esfuerzos para formular ante las autoridades demandas que representen los intereses de la totalidad de sus miembros. (FAO, 1994; Fox 1996; Flores y Rello, 2002).

Las ventajas de la organización han sido señaladas por diversos autores y desde diferentes puntos de vista. Hay quienes señalan a la organización social como un instrumento para poder participar de los beneficios del desarrollo (Contreras, 2000); como medio para crear poder en las comunidades locales mediante el involucramiento de las personas (Vargas, 2006); y como mecanismos de aprendizaje y desarrollo de conocimientos (Chiriboga, 2003).

Las organizaciones también son importantes desde el punto de vista del capital social, ya que facilitan las conexiones sociales, la cooperación y engendran la confianza entre sus miembros (Gordon, 2005) para emprender proyectos que beneficien al conjunto de la comunidad (Moyano, 2006). Machado (2000) señala que las organizaciones cumplen con otras funciones como facilitar la ejecución de proyectos; prestar servicios a sus miembros; asumir, en determinadas circunstancias, el suministro de bienes públicos a través de contratos con el estado; facilitar alianzas productivas entre actores; ser un mecanismo importante de difusión de información y facilitar la concertación. Gómez (2002) añade que el fortalecimiento de las organizaciones es fundamental para desarrollar la sociedad civil como un medio para avanzar en la democratización de la sociedad rural.

Existen diversos tipos de organizaciones con distinta naturaleza y diferentes ámbitos de actividad. Moyano (2006) destaca las siguientes: a) las que orientan su actividad a la defensa y representación de intereses; b) las que están especializadas en algún tipo de actividad económica; y c) las asociaciones de tipo corporativo. Otra forma de clasificar a las organizaciones es de acuerdo a su régimen legal (Rello, 1990), determinado por la calidad de los miembros que legalmente pueden formar parte de cada figura asociativa y las funciones que están autorizadas a realizar. Estas organizaciones pueden ser de primero, segundo y tercernivel.

Aún cuando existe consenso en la importancia que tienen las organizaciones en el desarrollo de una comunidad, existe una gran cantidad de organizaciones que no logran grouping and joining efforts in order to formulate demands that represent the interests of all its members. (FAO, 1994; Fox, 1996; Flores and Rello, 2002).

The advantages of an organization have been noted by several authors and from different points of view. Some point out that a social organization is an instrument to participate of development benefits (Contreras, 2000); also as a mean to build power in local communities through involving people (Vargas, 2006) and as learning and knowledge development mechanisms (Chiriboga, 2003).

The organizations are also important from the standpoint of social capital, as they facilitate social connections, cooperation and engender trust among its members (Gordon, 2005), to undertake projects that benefit the whole community (Moyano, 2006). Machado (2000), notes that organizations comply with other functions such as facilitating projects implementation, providing services to its members, in certain circumstances assuming the provision of public goods through contracts with the State, to facilitate partnerships between actors, being an important mechanism to disseminate information and promote cooperation. Gómez (2002), adds that strengthening organizations is essential to develop the civil society as a mean to advance in rural society democratization.

There are various types of organizations of different nature and different areas of activity. Moyano (2006), highlights the following: a) those that guide its activity to defense and representation of interests; b) those that are specialized in some type of economic activity; and c) corporate type associations. Another way to classify organizations is according to their legal regime (Rello, 1990), determined by the quality of members who can legally be part of each associative figure and functions that are authorized to perform. These organizations may be first, second and third level.

Although there is a consensus on the organizations' importance in communities' development, there are plenty of organizations that fail to consolidate and achieve its objectives, in fact many of them are formally registered even when they are not working and others were only formed as a mechanism to obtaining some government support and teamwork does not represent a commitment to their members, so they fail to become development drivers in their localities. 
consolidarse y cumplir sus objetivos, de hecho muchas de ellas aún cuando están registradas formalmente no funcionan y otras solo se formaron como mecanismos para obtener algún apoyo el gobierno, sin que el trabajo en grupo represente para los integrantes un compromiso, por lo que no logran convertirse en impulsoras del desarrollo de sus localidades.

De acuerdo a Schejtman y Berdegué (2004) el éxito o fracaso de las estrategias de acción colectiva dirigidas al mejoramiento de las condiciones de vida de las poblaciones rurales, depende de factores internos (valores, normas de conducta, sistemas de reglas formales, mecanismos para asegurar el cumplimiento de las reglas y compromisos y tipo de liderazgo); externos (comunicación y concertación de múltiples actores, vínculos con motores de sostenibilidad de la acción colectiva) y de contexto (individualismo versus solidaridad en el plano cultural, competencia versus cooperación en el plano económico, y democracia versus autoritarismo en el plano político).

Dado el papel que se le ha dado a la organización como elemento esencial en el desarrollo, parecería que la existencia de organizaciones en un territorio implica incidencia en el mejoramiento de las condiciones de la comunidad; sin embargo, existen factores que pueden incidir para que esto no suceda, por tal razón el propósito de este trabajo es identificar las causas que están originando que la organización no tenga impacto en el desarrollo del municipio y que deberán ser tomados en cuenta en una estrategia que permita a éstas el papel de ser motores de desarrollo en la región.

Dicha investigación se hizo a través de un estudio de caso en el municipio de Salinas, San Luis Potosí, en primera instancia para conocer la participación de los ciudadanos en organizaciones a través de una encuesta a diversos estratos de la población y en segundo lugar con entrevistas a las organizaciones existentes, para conocer su funcionamiento. Entre los resultados más importantes destacan el hecho que es un territorio con escasa participación, lo que da cuenta de la desarticulación de la sociedad; y por otro lado, las organizaciones que existen enfrentan problemas que van desde falta de objetivos e incumplimiento de acuerdos, así como falta de alianzas estratégicas y financiamiento para poder desarrollar sus actividades. Dicha problemática influye en el logro de sus objetivos y en su participación en el desarrollo del territorio.
According to Schejtman and Berdegué (2004), the success or failure of collective action strategies focused on improving the living conditions of rural people, depends on internal factors (values, behavioral norms, formal rules system, mechanisms to ensure rules and commitments compliance and leadership type); external (communication and coordination of multiple actors, links with engines of collective action sustainability) and context (individualism versus solidarity in culture terms, competition versus cooperation at economic level and democracy versus authoritarianism at political level).

Given the role that has been given to organization as an essential element in development, it would seem that existence of organizations in a territory implies an impact on improving the community conditions; but there are factors that can influence to prevent this from happening, for that reason the aim of this paper is to identify why an organization has no impact on municipal development and that it should be taken into account in a strategy that allows them to promote regional development.

This research was made through a case study in Salinas municipality, San Luis Potosí; first, to know the participation of citizens in organizations through a survey in various population strata and secondly with interviews to existing organizations in order to understand its operation. Among the most important results, it highlights the fact that it is an area with limited participation, which due to the breakdown of society and on the other hand, organizations are facing problems ranging from lack of purpose and breach of agreements, as well as lack of strategic alliances and financing to develop its activities. This problem affects the achievement of its objectives and its participation in territory development.

\section{MATERIALS AND METHODS}

The study area is located west of the state of San Luis Potosí, located at $95 \mathrm{~km}$ from the State's capital and 515 $\mathrm{km}$ from Mexico City. Among the most important activities in the region are farming and trade. The main crops are corn, beans, chilli pepper and alfalfa. Production is for self-consumption and surplus are sold locally and to the region. In livestock, most important herds in descending order are: sheep, goats, cattle and pigs (Plan Municipal de Desarrollo, 2007-2009). 


\section{MATERIALES Y MÉTODOS}

La zona de estudio se encuentra al oeste del estado de San Luis Potosí, localizado a $95 \mathrm{~km}$ de la capital del estado y a $515 \mathrm{~km}$ de la ciudad de México. Entre las actividades más importantes de la región están las agropecuarias y el comercio. Los principales cultivos son maíz, frijol, chile y alfalfa. La producción se destina al autoconsumo y cuando se tienen excedentes se comercializa a nivel local y hacia la región. En cuanto a ganadería, los hatos más importantes en orden descendente son ovinos, caprinos, bovinos y porcinos (Plan Municipal de Desarrollo, 2007-2009).

Sin embargo, las actividades agropecuarias se enfrentan a problemas como una precipitación errática y la obsoleta infraestructura de riego, que ocasionan rendimientos de producción muy bajos. Por otro lado la situación económica del municipio acentúa la incapacidad para la adquisición de insumos y equipo. En cuanto a la ganadería, la falta de forrajes debido a la utilización de un sistema de producción pecuaria extensivo y la degradación de agostaderos por el sobrepastoreo, proporciona índices de productividad bajos.

La situación crítica del sector agropecuario afecta otra de las actividades importantes en el municipio que es el comercio, éste se sostiene en gran parte por la cabecera municipal que se sitúa como importante centro de comunicación carretera entre los estados de San Luis Potosí y Zacatecas.

El índice de marginación del municipio lo ubica en el lugar 43 de 58 a nivel estatal (aunque el estado de San Luis Potosí ocupa el sexto lugar a nivel nacional), $70 \%$ de sus localidades se encuentran con uníndice de marginación alto (CONAPO, 2005).

De acuerdo al XII Censo General de de Población y Vivienda de 2000 efectuado por el Instituto Nacional de Estadística, Geografía e Informática (INEGI), Salinas tiene una población de 26985 habitantes. El 44.91\% de la población vive en localidades con menos de 5000 habitantes y $69.14 \%$ de la población ocupada cuenta con ingresos de hasta dos salarios mínimos.

Bajo este contexto, este trabajo se realizó con el propósito de identificar la participación de la población en organizaciones, se hicieron encuestas a diversos sectores de la población en 30 localidades y la cabecera municipal. Se aplicaron cuestionarios a niños, jóvenes, adultos y adultos mayores.
However, farming activities are facing problems such as erratic rainfall and obsolete irrigation infrastructure, causing very low production yields. On the other hand, the municipality's economic situation underscores the inability to purchase inputs and equipment. As for livestock, lack of forage due to the use of a system of extensive livestock production and rangeland degradation by overgrazing, provides low productivity rates.

The agricultural sector's plight affects other important activities in the municipality such as trade, it is held largely by the county seat that stands as an important center of communication between the states of San Luis Potosí and Zacatecas.

The municipality deprivation index puts it at place 43 out of 58 at state level (although San Luis Potosí ranks sixth nationally). $70 \%$ of its locations are in a high exclusion rate (CONAPO, 2005).

According to the XII Population and Housing General Census of 2000, conducted by the National Institute of Statistics, Geography and Informatics (INEGI), Salinas has a population of 26985 inhabitants. $44.91 \%$ of population lives in areas with less than 5000 habitants and $69.14 \%$ of the employed population has incomes up to two minimum wages.

In this context, this paper was carried out to identify the people's participation in organizations; surveys were conducted in various sectors of population in 30 localities and the county seat. Questionnaires were applied to children, youths, adults and seniors. The sample size was obtained through simple random method, by population size, according to data of population and housing Census 2005 of the National Institute of Statistics, Geography and Informatics (INEGI) with a $90 \%$ of representativeness of the municipality's total population.

On the other hand, 102 producers were interviewed; this sample was obtained based on beneficiaries of Direct Support to Field Program 2007, registered at the Ministry of Agriculture, Livestock, Rural Development, Fisheries and Food (SAGARPA by its Spanish acronym).

In order to know the operation of the organizations in the municipality, an interview was performed to those who are active, from a review in the property's public registry of the municipality on registered organizations since 2003 
El tamaño de muestra se obtuvo a través del método simple aleatorio, por tamaño de población, de acuerdo a datos del censo de población y vivienda de 2005 del Instituto Nacional de Estadística, Geografía e Informática (INEGI) con una representatividad de $90 \%$ de la población total del municipio.

Por otro lado se entrevistó a 102 productores, dicha muestra se obtuvo en base a los beneficiarios del Programa de apoyos directos al campo 2007, registrados en la Secretaría de Agricultura, Ganadería, Desarrollo Rural, Pesca y Alimentación (SAGARPA).

A efecto de conocer el funcionamiento de las organizaciones del municipio, se realizó una entrevista a aquellas que se encuentran activas, a partir de una revisión en el registro público de la propiedad del municipio sobre las organizaciones registradas desde 2003, que estuvieran relacionadas con aspectos agropecuarios. Se encontraron 13 organizaciones que fueron incorporadas al estudio; sin embargo, en la actualidad cinco de ellas, no realizan actividades. Asimismo, se aplicaron entrevistas a informantes clave relacionados con éstas.

Se diseñó un cuestionario en el cual se incluyeron preguntas dirigidas a los dirigentes eintegrantes de las organizaciones en estudio. Los temas incluidos en el cuestionario están relacionados al funcionamiento de la organización, retomando elementos como su origen, propósitos, estructura, necesidades y problemática, que permitiera identificar sus fortalezas y limitaciones y su participación en actividades dentro del municipio.

\section{RESULTADOS Y DISCUSIÓN}

\section{La participación social en el desarrollo del municipio}

Dentro de la concepción actual del desarrollo, la participación de las personas en las decisiones que los afectan es necesaria para que sea un proceso sostenible, la mayor o menor participación da cuenta del grado de articulación de la sociedad y de las implicaciones que esto puede tener para el desarrollo del territorio.

Para el caso del municipio de Salinas, los resultados obtenidos (Cuadro 1) indican que hay un debilitamiento en la participación ciudadana, de manera general $76 \%$ de la población no participa en organizaciones; sólo en el caso that were related to agricultural issues. 13 organizations were found and were incorporated into the study; however, nowadays, five of them do not perform any activities at all. Also, interviews were applied to key informants related to them.

A questionnaire was designed which included questions for leaders and members of the organizations under study. The topics included in the questionnaire are related to organizational operation, taking up elements such as its origin, purpose, structure, needs and problems; in order to identify their strengths, limitations and participation in activities within the municipality.

\section{RESULTS AND DISCUSSION}

\section{Social participation in municipality development}

Within the current concept of development, people's participation in decisions that affect them is necessary for a sustainable process, the degree of participation represents the society's articulation level and the implications this may have in the area's development.

In the case of Salinas, results obtained (Table 1), indicate a decline in civic participation, generally $76 \%$ of the population does not participate in organizations; only young people present an important percentage, $43 \%$ of them reported to participate in some kind of organization, adults followed in importance with $29.5 \%$. Note that in both cases, the organization type to which they belong is mostly sports.

Another indicator of decline is the decrease in participation percentage in presidential elections of United Mexican States, according to the Federal Electoral Institute (IFE), in 2000 at municipal level there was a citizen participation of $65.51 \%$, while for 2006 it was of $58.98 \%$; i. e., there was a decrease of $6.53 \%$.

The low participation of society, results in fewer development opportunities implying a disjointed society that can hardly achieve common benefits. Therefore, involving the municipality society would mean that the people would take an active part in whatever they want to develop and become the main agents of them (Caride, 2005). 
de los jóvenes se presenta un porcentaje importante, $43 \%$ de estos indicaron participar en algún tipo de organización. Le siguen en importancia los adultos con $29.5 \%$. Cabe señalar que en ambos casos el tipo de organización al que mayormente pertenecen es deportiva.
On the other hand, it also highlights results of producer's survey, $81 \%$ of respondents did not belong to any organization that articulates and represents them, making it difficult to channel profits from policies and programs intended to favor them, as pointed out by Contreras (2000).

\section{Cuadro 1. Empatía por el trabajo en equipo y participación en organizaciones de diversos estratos sociales del municipio de Salinas.}

Table 1. Empathy for teamwork and participation in organizations of various social strata in the municipality of Salinas.

\begin{tabular}{|c|c|c|c|c|c|c|}
\hline \multirow[t]{2}{*}{ Estrato social } & \multirow[t]{2}{*}{$\begin{array}{l}\text { Núm. de } \\
\text { entrevistas }\end{array}$} & \multicolumn{2}{|c|}{$\begin{array}{l}\text { Empatía por } \\
\text { trabajo en grupo }\end{array}$} & \multicolumn{2}{|c|}{$\begin{array}{l}\text { Participa en alguna } \\
\text { organización }\end{array}$} & \multirow[t]{2}{*}{ Tipo de organización } \\
\hline & & $\mathrm{Si}(\%)$ & No $(\%)$ & $\mathrm{Si}(\%)$ & No $(\%)$ & \\
\hline Niños & 137 & 87 & 13 & 24 & 76 & Deportiva, artística, estudiantil, religiosa \\
\hline Jóvenes & 77 & 76.6 & 23.3 & 43 & 57 & $\begin{array}{l}51 \% \text { deportiva, } 9 \% \text { artística, } 9 \% \text { laboral, } 6 \% \\
\text { productiva, } 15 \% \text { religiosa, } 3 \% \text { altruista, } 3 \% \\
\text { vecinal, } 30 \% \text { política y } 3 \% \text { estudiantil. }\end{array}$ \\
\hline Adultos & 254 & 58.2 & 41.8 & 29.5 & 70 & $\begin{array}{l}33 \% \text { deportiva, } 14.8 \% \text { cultural, } 26.6 \% \text { laboral, } \\
8 \% \text { productiva, } 32 \% \text { religiosa, } 9 \% \text { altruista, } 8 \% \\
\text { vecinal, } 10 \% \text { política, } 12 \% \text { estudiantil }\end{array}$ \\
\hline Adultos mayores & 76 & 39.5 & 60.5 & 1.3 & 98.7 & Sin dato \\
\hline Productores & 102 & 56 & 44 & 19 & 81 & $\begin{array}{l}26.3 \% \text { deportiva, } 26.3 \% \text { productiva, } 21 \% \text { laboral, } \\
10.5 \% \text { religiosa, } 5.2 \% \text { política y } 5.2 \% \text { vecinal }\end{array}$ \\
\hline Total & & 63.4 & 36.5 & 23.3 & 76.5 & \\
\hline
\end{tabular}

Otro indicador de dicho debilitamiento es la disminución en el porcentaje de participación en las votaciones sexenales para elección del Presidente de los Estados Unidos Mexicanos, de acuerdo al Instituto Federal Electoral (IFE), a nivel municipal, en 2000 hubo una participación ciudadana de $65.51 \%$ mientras que para 2006 fue $58.98 \%$; es decir, hubo una disminución de $6.53 \%$.

La escasa participación de la sociedad resulta en menores oportunidades de desarrollo, pues implica una sociedad desarticulada que difícilmente puede lograr beneficios comunes que afecten el territorio. Por tanto, lograr la participación de la sociedad del municipio implicaría que las personas tomen parte activa en las acciones que se desea desarrollar y se conviertan en las principales agentes de las mismas (Caride, 2005).

Por otro lado, también destacan los resultados obtenidos de la encuesta a productores, $81 \%$ de los entrevistados no pertenecen a ningún tipo de organización que los articule y los represente, lo que dificulta la canalización de beneficios provenientes de políticas y programas destinados a favorecerlos como lo señala Contreras (2000).
It should be noted that none of the interviewed farmers mentioned the ejido (organizational structure specified by the Land Law for distribution and use of land), as an organization form, which means that this organization form is not conceived as a structure that represents their interests. Engaging communities for its economic and social development, as indicated by González (2006), requires changes in attitudes and promote the necessary awareness among the population, aimed at creating the right conditions for them to responsibly participate in their own and their people destiny.

Therefore, it is necessary to find strategies that involve people, considering their participation in identifying needs and potential solutions for the territory, helping them to develop their skills, knowledge, confidence and empowering them to organize themselves appropriately and obtaining voice in decision-making and power in the political system (Armstrong, 1993).

A strategy to promote territory development should include as the first element, mechanisms that stimulate territories, by encouraging in people an open-minded 
Cabe señalar que ninguno de los productores entrevistados menciono al ejido (estructura organizativa que especifica la Ley Agraria para el reparto y uso de la tierra), como una forma de organización, lo que implica que no se concibe a esa forma de organización como una estructura que represente sus intereses.

Lograr la participación de las comunidades para su desarrollo económicoy social, como lo señala González (2006) requiere propiciar cambios mentales y de actitudes necesarias en la población, encaminados a crear las condiciones adecuadas para que participe responsablemente en su propio destino y el de su pueblo.

Por lo anterior, es necesario buscar estrategias que permitan involucrar a las personas considerando su participación en la identificación de las necesidades y las soluciones potenciales del territorio, ayudándoles a desarrollar sus habilidades, conocimiento, confianza y empoderándolos para que se organicen de forma apropiada, que les permita obtener voz en la toma de decisiones y poder en el sistema político (Armstrong, 1993).

Una estrategia para promover el desarrollo del territorio deberá incluir como primer elemento mecanismos que dinamicen los territorios, fomentando en las personas una actitud abierta y decidida para involucrarse en las dinámicas y los procesos sociales y culturales que los afecten y para responsabilizarse en la medida que les corresponda.

Cabe señalar que entre los resultados encontrados $63.4 \%$ de la población entrevistada (Cuadro 1), señaló que le gusta trabajar en grupo, lo cual es favorable desde el punto de vista de la disposición para participar en actividades que pudieran implementarse en el territorio, incentivando la formación de organizaciones que realmente cumplan con sus objetivos $\mathrm{y}$ beneficien a sus integrantes y su comunidad, sobre todo con los niños y jóvenes que obtuvieron los porcentajes más altos, que implica la posibilidad de incidir en ellos a esa edad para fortalecer el trabajo en grupo y la organización como alternativa para el logro de objetivos.

\section{Las organizaciones en el desarrollo local}

La organización es vista como una importante expresión de la participación de las personas en el desarrollo de un territorio, pues es a través de éstas que se logran beneficios colectivos para sus asociados y los lugares donde se desenvuelven. Sin embargo, lograr incidir en el desarrollo requiere and determined attitude to engage them in dynamics and social and cultural processes that affect them and to be correspondingly responsible.

It should be noted that among the results, $63.4 \%$ of the surveyed population (Table 1), said that they like working in groups, which is favorable from the standpoint of willingness to participate in activities that could be implemented in the territory, encouraging the organizations formation that truly meet their goals and benefit their members and community, especially children and youths who obtained the highest percentages, implying a possibility of influencing them at that age, to strengthen group work and the organization as an alternative for achieving goals.

\section{Organizations in local development}

The organization is seen as an important expression of people's participation in the development of a territory; it is through them that collective benefits are achieved for its members and places where they operate. But making an impact on development requires strengthened organizations that achieve compliance of its objectives and serve as engines for regional development, which requires a major effort from both partners and institutions operating around to provide tools that allow them to stay.

In the municipality of Salinas, the research results show two types of organizations in the territory, but given their situation, they have not driven development in the region, to understand its operation and problems will guide for concrete actions that will allow them to be development drivers of the region.

Two types of organizations legally constituted were found, on one hand Societies of Rural Production (SRP), which according to Moyano's classification (2006), are economic organizations that are defined by specific tasks linked to economic-productive ambit of individuals within them (Table 2). On the other hand, the Local LivestockAssociation (LLA) which, following the same classification, is a partnership aimed at defense and interests representation, its goal is the development of its members as breeders. Both are first level organizations.

The time of formation of SRP is 1.6 years on average (Table 2), its origin is motivated by the intervention of an academic institution within the framework of crops 
organizaciones fortalecidas que logren el cumplimiento de sus objetivos y que sirvan de motores para el desarrollo de la región, que requiere un esfuerzo importante tanto de los asociados, como de las instituciones que actúan a su alrededor para ofrecerles las herramientas que permitan su permanencia.

En el caso del municipio de Salinas, los resultados de la investigación muestran dos tipos de organizaciones asentadas en el territorio, pero que dada su situación no han impulsado el desarrollo en la región, entender su funcionamiento y su problemática dará pautas para concretar acciones que les permitan ser impulsoras de desarrollo en la región.

Se encontraron dos tipos de organizaciones constituidas legalmente; por un lado las Sociedades de Producción Rural (SPR) que de acuerdo a la clasificación de Moyano (2006) son organizaciones económicas que se definen por la realización de tareas específicas ligadas al ámbito de lo productivo-económico de los individuos que las integran (Cuadro 2). Por otro lado, la Asociación Ganadera Local (AGL) la cual, siguiendo esa misma clasificación, se encuentra dentro de una asociación orientada a la defensa y representación de intereses, para ésta su objetivo es el desarrollo de sus afiliados en su condición de ganaderos. Ambas son organizaciones de primer nivel. conversion in the region. The idea of organizing does not come from them and there is discrepancy between the representatives and the other members, about the purpose of their training. This has important implications since it is necessary that the objectives are clear to all members because, as noted by Chiavenato (2000), from them, the organization establishes strategies, policies and procedures that will guide their actions.

The problems faced by SRP are very similar because the source is the same. This implies that they have organized themselves because is an opportunity for profit, but they do not see it as a long-term project of their own. González (2006), notes that the decision to participate in an organization, allows the members to develop an ownership sense of the actions they perform, thereby mobilizing energies and efforts for their progress and to strength the likelihood of sustainability.

The SRP are within a context of rural economy, where bonds of trust and kinship are overriding. This is an advantage, because there is greater commitment and solidarity within the group, but it is also true that it can be dominating the thinking of the family member who has more authority and compliance of rules and agreements is more relaxed. As noted by Wright (2005), entrenched

\section{Cuadro 2. Características generales de las organizaciones del municipio Salinas.}

Table 2. General characteristics of organizations in the municipality of Salinas.

\begin{tabular}{lccccccc}
\hline \multirow{2}{*}{ Nombre de la organización } & \multirow{2}{*}{ Figura asociativa } & \multirow{2}{*}{ Socios } & \multicolumn{3}{c}{ Sexo } & \multirow{2}{*}{ origen } & \multirow{2}{*}{ Actividad principal } \\
\cline { 3 - 7 } & & M & H & & \\
\hline Agroproductores Unidos del Bajío & SPR & 13 & 7 & 6 & 2007 & Producción de cultivos básicos \\
Productores agrícolas de Diego Martín & SPR & 29 & 1 & 28 & 2007 & Producción de cultivos básicos \\
Productores agrosilvopastoriles salinenses & SPR & 16 & 3 & 13 & 2006 & Producción de cultivos básicos \\
Productores agrosustentables del potro & SPR & 18 & 4 & 14 & 2007 & Producción de cultivos básicos \\
Productores de forraje y grano del Altiplano & SPR & 12 & 2 & 10 & 2007 Producción cultivos básicos \\
Asociación ganadera local & AC & 106 & 10 & 96 & 1945 Ganado ovino y bovino \\
\hline
\end{tabular}

$\overline{\mathrm{SPR}}=$ asociación de producción rural; $\mathrm{AC}=$ asociación civil.

El tiempo de formación de las SPR es de 1.6 años en promedio (Cuadro 2), su origen es motivado por la intervención de una institución académica en el marco de un proyecto de reconversión de cultivos en la región. La idea de organizarse no nace de ellos y hay discrepancia entre los representantes y el resto de los integrantes en el propósito de su formación. Lo anterior tiene implicaciones importantes social structures based on kinship and patron-client relationships in rural communities, directly affect the way how the organizations operate.

On the other hand, SPR do not have clarity in pursued objectives, there are no rules or responsibilities accepted by partners. According to Berdegué(2000), a successful business 
pues es necesario que los objetivos sean claros para todos los integrantes, ya que como señala Chiavenato (2000) a partir de ellos, la organización establece las estrategias, políticas y procedimientos que guiaran su actuación.

La problemática que enfrentan las SPR es muy similar dado que el origen es el mismo. Esto implica que se han organizado por ser una oportunidad para obtener un beneficio, pero no se ve como un proyecto propio a largo plazo. González (2006) señala que la decisión de participar en una organización permite que los integrantes desarrollen el sentimiento de propiedad de las acciones a realizar, movilizando con ello las energías y esfuerzos para que éstas avancen y se fortalezca su posibilidad de sostenibilidad.

Las SPR se mueven en un contexto de economía campesina donde los lazos de confianza y parentesco son primordiales. Si bien lo anterior es una ventaja, pues hay mayor compromiso y solidaridad al interior del grupo, es cierto también que puede dominar la forma de pensar del integrante que en la familia tenga mayor autoridad y es más relajado el cumplimiento de normas y acuerdos. Como señala Wright (2005), las estructuras sociales arraigadas basadas en el parentesco y las relaciones patrón-cliente en las comunidades rurales afectan directamente la forma en cómo operan las organizaciones.

Por otro lado, en las SPR dado que no existe claridad en los objetivos que se persiguen, tampoco hay reglas y responsabilidades aceptadas por los socios. De acuerdo a Berdegué (2000) una empresa exitosa se caracteriza por un buen desempeño institucional, el cual se expresa en un sistema de normas que ordenan las relaciones entre los socios, entre éstos y la organización y entre ésta y el exterior.

Las SPR no cuentan con financiamiento deningún tipo, por lo que la falta de recursos económicos para el emprendimiento de proyectos restan potenciales de competitividad (Camacho et al., 2005) frente a otras organizaciones que cuentan con ese tipo de apoyos.

La capacitación que han recibido es de carácter técnico, ninguna ha tenido capacitación en los ámbitos comercial, financiero y de administración por lo que carecen de las herramientas para atender estas cuestiones, por otro lado no han logrado establecer alguna alianza y obtener apoyos externos importantes (financiamiento y asesoría) para enfrentar la problemática que presentan al respecto o que les permitan incidir en las decisiones que los afectan. is characterized by a good institutional performance, which is expressed in a system of rules that order the relations between partners, between them and the organization and between it and the outside.

The SRP do not have funding whatsoever, so the lack of financial resources to undertake projects, restrains competitive potential (Camacho et al., 2005), compared to other organizations that have such support.

The training they have received is of a technical nature, none has had commercial, financial and administrative training, so they lack of tools to address these issues, on the other hand, they have failed to establish an alliance for significant external support (funding and advice), to face their problems or allow them to influence decisions that affect them.

These organizations (SRP) are quite young and have not been consolidated; their problems need to focus efforts in solving internal issues such as: statement of objectives, values, rules and an organizational structure that suits their needs, elements that have been fundamental in the success of an organization.

The LLA has 64 years of operation (Table 2), it arises from the interest of the most important farmers in the region in order to strengthen animal husbandry, which at that time was one of the peak activities.

As an old organization, it has consolidated its form of internal work, it has clear objectives for the members, rules and defined structure; those who integrate it have a clear expectation of what can be obtained by paying the membership.

This organization has been able to obtain financing from public agencies throughout its trajectory, technical training for its members and partnerships with suppliers and cattle buyers, all of which have given some stability.

The problem of this organization is that there are power struggles within, lack of transparency in resources management, nonperforming loans, inadequate funding, lack of infrastructure and partnerships that do not represent real benefits for the partners.

Given its problems, this organization has not impacted the territory's development, although in the beginning it meant a significant boost to the development dynamics of the region, achieving the representation of interests of an important 
Estas organizaciones (SPR) son muy jóvenes, y no han logrado consolidarse, su problemática requiere enfocar esfuerzos que permitan solucionar cuestiones internas tales como: planteamiento de objetivos, valores, reglas y una estructura organizativa acorde a sus necesidades, elementos que del análisis de experiencias exitosas han sido fundamentales para el éxito de una organización.

En el caso de la AGL, ésta tiene 64 años de funcionamiento (Cuadro 2), surge del interés de los ganaderos más importantes de la región para consolidar la ganadería, que en ese momento era una de las actividades con mayor auge.

Por ser una organización de más tiempo ha logrado consolidarse en su forma de trabajo interno, con objetivos claros para los socios, reglamento y una estructura definida, ya que quienes la integran tienen una expectativa clara de lo que pueden obtener, al pagar la membrecía.

Esta organización a lo largo de su trayectoria ha logrado obtener financiamiento de instancias públicas, capacitación técnica para sus agremiados, alianzas con proveedores y compradores de ganado, elementos que le han dado cierta estabilidad.

La problemática de esta organización radica en que hay conflictos de poder al interior, falta de transparencia en el manejo de los recursos, cartera vencida, escaso financiamiento, falta de infraestructura, y alianzas que no representan beneficios reales para los socios.

Dada su problemática esta organización no ha incidido en el desarrollo del territorio, si bien en sus inicios significo un impulso importante en la dinámica del desarrollo de la región al lograr la representación de los intereses de un sector importante en la región, ahora se expresa su incapacidad para lograr el bienestar de sus integrantes, hacer los cambios pertinentes en cuanto a sus formas de trabajo, estructura organizativa y la forma de llegar a acuerdos con diversos agentes que puedan incidir en los procesos que desarrollan.

Al igual que las SPR, en esta organización se requiere poner énfasis en la capacitación, en aspectos administrativos, manejo de grupo y solución de conflictos, de igual manera se requiere de la preparación de cuadros de líderes capaces y honestos que conduzcan a la organización hacia el logro de beneficios para todos. Estos puntos deberán ser atendidos por una estrategia que permita el desarrollo de las capacidades de las personas, al respecto Klisberg (2001) sector, it is now expressed its inability for achieving the welfare of its members, making appropriate changes in their working methods, organizational structure and how to reach agreements with different agents that may affect the processes they develop.

As the SRP, this organization requires to emphasize the training in administrative, group management and conflict resolution, just as it requires the preparation of tables of capable and honest leaders who could lead the organization towards achieving benefits for all of them. These points should be addressed by a strategy that allows development of the people's capacities; in this regard Klisberg (2001), states that achievements of organizations have had as pillars, human capital formation and social development, enhancing social capital over financial capital, as well as innovative management ways.

In both cases it is necessary to find mechanisms to increase people's participation. Even when these organizations are legally constituted, one of the concerns expressed by them is the lack of commitment of members with the organization and difficulty to meet agreements made, so it will be necessary to strengthen empowerment issues within organizations. According to Contreras (2000), subjects through social and economic empowered organizations could construct spaces of local power in territories in which they operate.

Thus a strategy is needed to strengthen and support the building of strong social organizations with capacity and legitimacy as mentioned by Echeverri and Ribero (2002), which may affect public policies and decisions that affect them.

\section{CONCLUSIONS}

The participation of men and women in the formulation of strategies, is essential for communities development through the organization and is one of the pillars of local development.

It is necessary to increase the associative territory in order to reach greater development possibilities, being an alternative the work with children and youths through the formation of work teams in various activities to identify the benefits of the organization. 
expresa que los logros de las organizaciones han tenido como pilares la formación de capital humano y social, el potenciar el capital social sobre el financiero, así como formas de gestión novedosas de las organizaciones.

En ambos casos, es necesario buscar mecanismos que incrementen la participación de las personas, aun cuando estas organizaciones están constituidas legalmente, uno de los problemas manifestados por ellas es el escaso compromiso de los integrantes con la organización y la dificultad para cumplir los acuerdos establecidos, lo que señala que será necesario reforzar cuestiones de empoderamiento dentro de las organizaciones. De acuerdo a Contreras (2000) los sujetos a través de organizaciones económico sociales empoderadas, podrían construir espacios de poder local en los territorios que se insertan.

De esta manera se hace necesario emprender una estrategia de fortalecimiento y apoyo a la construcción de organizaciones sociales fuertes, con capacidad y legitimidad como lo menciona Echeverri y Ribero (2002), que puedan incidir en las políticas públicas y las decisiones que los involucren.

\section{CONCLUSIONES}

La participación de hombres y mujeres en el planteamiento de estrategias, es indispensable para el desarrollo de las comunidades a través de la organización, y es uno de los pilares en el desarrollo local.

Se requiere incrementar el tejido asociativo del territorio que alcance mayores posibilidades de desarrollo, siendo una alternativa el trabajo con los niños y jóvenes a través de la formación de equipos de trabajo en diversas actividades, que permita identificar las ventajas de la organización.

Es necesario incentivar la participación en el territorio, involucrando a sociedades y organizaciones a tomar parte en las decisiones que se lleven a cabo en el municipio y que les afectan para darle solución a sus problemas.

Las organizaciones asentadas en un territorio, deben ser impulsoras de desarrollo a través de la generación de capital social, facilitar la ejecución de proyectos y dinamizar el territorio a través del involucramiento de las personas.
It is necessary to encourage participation in the territory, involving society and organizations to take part in decisions of the municipality that affect them in order to solve their problems.

The organizations established in a territory should be promoting development through the generation of social capital, to facilitate the implementation of projects and brisk the territory by involving people.

End of the English version

\section{LITERATURA CITADA}

Araujo, J. 1982. Agenda para el futuro. Balance y perspectivas del desarrollo rural en América Latina y el Caribe. Una visión desde el IICA. Costa Rica. Serie de Desarrollo Institucional. Núm. 13.382 p.

Armstrong, J. 1993. Making community involvement in urban regeneration happen-lessons from the United Kingdom. Community Development J. 28:355-361.

Berdegué, J. 2000. Cooperando para competir, factores de éxito de las empresas asociativas campesinas RIMISP. Chile. 100 p.

Calvillo, M. y Favela, A. 2004. Dimensiones cuantitativas de las organizaciones civiles en México. En Jorge Cadena-Roa (coord). Las organizaciones civiles mexicanas hoy. UNAM. $376 \mathrm{p}$.

Camacho, P. Marlin, C. y Zambrano, C. 2005. Estudio regional sobre factores de éxito de empresas asociativas rurales. Ruralter. Plataforma regional andina. $47 \mathrm{p}$.

Caride, J. 2005. La animación sociocultural y el desarrollo comunitario como educación social. Revista de Educación. 336:73-88.

Carpio, J.2001. Desarrollo local en los espacios rurales Polis. Revista de la Universidad Bolivariana. 2(1):1-7.

Cebrián,A. 2003. Génesis, método y territorio del desarrollo rural con enfoque local. Papeles de Geografía. 38:61-76.

Contreras, R. 2000. Empoderamiento campesino y desarrollo rural. Revista Austral de Ciencias Sociales. 4:55-68.

Chiavenato, I. 2000. Introducción a la teoría general de la administración. Mc Graw Hill. $5^{\text {ta. }}$ edición. México. $1056 \mathrm{p}$. 
Chiriboga, M. 2003. Innovación, conocimiento y desarrollo rural. Revista Debate Agrario. 26:119-149.

Food and Agriculture Organization (FAO). 1994. Participación campesina para una agricultura sostenible en países de América Latina. Serie Participación Popular. URL: http://www.fao.org.

Flores, M. y Rello, F. 2002.Capital social rural. Experiencias de México y Centroamérica. Comisión Económica para América Latina y el Caribe. Plaza y Valdés S.

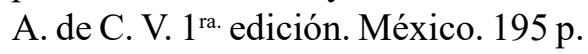

Fox, J. 1996. ¿How does civil society thicken? The political construction of social capital in rural Mexico. World Development. 24(6):1089-1103.

Consejo Nacional de Población (CONAPO). 2005. Índices de Marginación. URL:http://www.conapo.gob.mx.

Instituto Nacional de Estadística, Geografía e Informática (INEGI). 2007. Censo agropecuario 2007 y VII Censo Agrícola, Ganadero y Forestal 2007. URL: http://www.inegi.org.mx.

Gómez, S. 2002. Organización campesina en Chile: reflexiones sobre su debilidad actual. Revista Austral de Ciencias Sociales. 8:3-18.

González, A. 2006. La participación de las organizaciones comunitarias en el desarrollo local sostenible. Caso sector Guayapa, Parroquia Curimagua, Municipio de Petit, Estado de Falcón, Venezuela. Multiciencias. 6(3):250-256.
Gordon, S. 2005. Confianza, capital social y desempeño de organizaciones. Revista Mexicana de Ciencias Políticas y Sociales. 193(47):41-55.

Klisberg, B. 2001. El capital social. Dimensión olvidada del desarrollo. Venezuela Editorial Panapo. 154 p.

Machado, A. 2000. El papel de las organizaciones en el desarrollo rural. Red de bibliotecas virtuales de ciencias sociales de América Latina y el Caribe (CLACSO). $11 \mathrm{p}$.

Moyano, E. 2006. El asociacionismo en el sector agroalimentario y su contribución a la generación de capital social. Documentos de trabajo. Instituto de Estudios Sociales Avanzados (CSIC). 20 p.

Nogueiras, L. 1996. La práctica y la teoría del desarrollo comunitario. Descripción de un modelo. Madrid, España. Narcea S. A. de ediciones. 163 p.

Rello, F. 1990. Las organizaciones de productores rurales en México. Universidad Autónoma de México. 386 p.

Schejtman, A. y Berdegué, J. 2004. Desarrollo territorial rural. Debates y temas rurales 1:7-46.

Vargas, J. 2006. Comunidades y organizaciones locales en la gobernabilidad y gestión del desarrollo. Nómadas. Revista Crítica de Ciencias Sociales y Jurídicas. 13:1-18.

Wright, K. 2005. El lado más oscuro de las microfinanzas. Evidencias de Cajamarca. Perú Revista Debate Agrario. 38:90-108. 